\title{
Expression of an islet regenerating (reg) gene in isolated rat islets: effects of nutrient and non-nutrient growth factors
}

\author{
P.J.Francis, J. L. Southgate, T.J. Wilkin and A.J. Bone \\ Endocrine Section, Medicine II, Southampton General Hospital, Southampton, UK
}

\begin{abstract}
Summary. The expression of a novel regenerating (reg) gene has been reported previously in the regenerating islets of a surgical model of diabetes in rats. We exposed collagenaseisolated rat islets for three days to nutrient and non-nutrient growth factors in minimally supplemented RPMI medium ( $2.7 \mathrm{mmol} / 1$ glucose, $2 \%$ fetal calf serum), and investigated the relationship between reg gene expression and islet cell replication. RNA was prepared from half of the islets by homogenisation in guanidinium isothiocyanate followed by phenol/chloroform extraction. Northern/dot blot analyses were used to semi-quantify reg mRNA. Islet cell replication was estimated by culturing the remaining islets in radiolabelled thymidine to determine de novo DNA synthesis. Thymidine uptake was stimulated by the following factors: $11 \mathrm{mmol} / \mathrm{l}$ glucose (50\% increase); $10 \%$ amino acids ( $126 \%$ increase); $10 \%$ fetal calf serum (39\% increase); $100 \mathrm{ng} / \mathrm{ml}$ insulin $(45 \%$
\end{abstract}

increase); $250 \mathrm{ng} / \mathrm{ml}$ growth hormone (65\% increase); $1.5 \mathrm{nmol} / 1$ aldosterone $(29 \%$ increase $) ; 2 \mathrm{U} / \mathrm{ml}$ platelet derived growth factor ( $116 \%$ increase). The results are expressed as a percentage of the thymidine incorporated into control islets cultured in minimal RPMI $(1118 \pm 100$ (SD) $\mathrm{cpm} / \mu \mathrm{g}$ protein, $n=15$ ). Increased islet cell replication was paralleled in each case by a clear rise in reg mRNA expression compared to controls. Furthermore, the rank order for reg gene expression was the same as that for thymidine uptake $(r=0.90)$. The present findings suggest a clear association between reg gene expression and islet cell replication in vitro, and are the first to demonstrate reg gene expression in response to individual growth factors.

Key words: Islets, growth factors, replication, gene expression.
Autoimmune insulitis leads to the progressive loss of Beta cells of the islets of Langerhans and results in Type 1 (insulin-dependent) diabetes mellitus. It has been proposed that Beta-cell regeneration may occur in an attempt to offset this destructive process, since some patients exhibit morphological and functional signs of returning insulin production during the early stage of the disease [1].

Terazono et al. showed that the administration of DNA repair enzyme inhibitors such as nicotinamide to $90 \%$ depancreatised rats induced islet regeneration, and led to an improvement in the surgical diabetes [2]. Screening of the regenerating islet-derived cDNA library from the rats revealed a novel single copy gene which encodes a 165 amino acid secreted protein. The gene has been termed the "islet regenerating" or "reg" gene. Further studies identified the reg protein in the secretory vesicles of Beta cells [3]. Interestingly, prediction of the three-dimensional structure of the protein indicates homology with the lectins, a family of growth-promoting molecules $[4,5]$.

Subsequent studies both in animal models of islet regeneration and in tumour cell lines have confirmed en- hanced reg gene transcription, thus linking expression to normal and transformed cell proliferation $[3,6]$. Although these studies implied a trophic role for the reg gene in Beta cells, the question still remains whether a constant association exists between expression of the reg gene and Beta-cell replication.

The aim of this study was to expose isolated rat islets to nutrient and non-nutrient growth factors in a well-defined tissue culture system in order to investigate the relationship between reg gene expression and islet cell DNA synthesis.

\section{Materials and methods}

\section{Animals}

Normal adult female Wistar rats were used throughout the study. The method for rat islet isolation was adapted from that of Hehmke et al. [7]. The bile duct of a freshly killed rat was cannulated and the pancreas inflated by injection of $10 \mathrm{ml}$ of a $1 \mathrm{mg} / \mathrm{ml}$ collagenase solu- 
tion (Type II, Sigma Chemical Co., Poole, UK). The pancreas was then excised. Following incubation $\left(16 \mathrm{~min}, 37^{\circ} \mathrm{C}\right)$, two washes in ice cold Hanks' balanced salt solution (HBSS) and filtration through a $500 \mu \mathrm{m}$ mesh, the remaining pancreatic tissue was pelleted by centrifugation $\left(2 \mathrm{~min}, 50 \mathrm{~g}, 4^{\circ} \mathrm{C}\right.$ ). Islet tissue present was then isolated by dextran gradient centrifugation $\left(15 \mathrm{~min}, 400 \mathrm{~g}, 4^{\circ} \mathrm{C}\right.$; dextran concentrations: $28 \%, 21.2 \%, 18.2 \%, 10.6 \%$ ).

\section{Cell culture}

The isolated islets (in groups of 200) were transferred to $10 \mathrm{ml}$ sterile, non-adherent cell culture dishes and cultured for $24 \mathrm{~h}$ in $7.5 \mathrm{ml}$ RPMI $1640(11.1 \mathrm{mmol} / \mathrm{l}$ glucose, $10 \%$ fetal calf serum, $100 \mathrm{U} / \mathrm{ml}$ penicillin, $100 \mathrm{U} / \mathrm{ml}$ streptomycin, $100 \mathrm{U} / \mathrm{ml}$ gentamycin, $\mathrm{pH} 7.3$ ) to allow recovery from the isolation procedure. After this initial period, growth factors were added. The cells were cultured in RPMI 1640 medium $(2.7 \mathrm{mmol} / 1$ glucose, $2 \%$ fetal calf serum, penicillin, streptomycin and gentamycin as above) for $48 \mathrm{~h}$, at $37^{\circ} \mathrm{C}$, in a humidified atmosphere of $5 \%$ carbon dioxide and air and the medium changed after $24 \mathrm{~h}$. Islet viability was confirmed by microscopic examination, with no obvious changes in islet size or morphology.

\section{Growth factors}

Growth factors were selected to represent the different second messenger systems of the Beta cell and were prepared to the following concentrations by mixing or dissolving in control medium: $10 \%$ amino acids solution ( $50 \times$ Basal Media Earle's containing $50 \%$ volume/volume (v/v) amino acids (Sigma) supplemented with L-glutamine); $10 \%$ fetal calf serum (Imperial Laboratories Ltd., Andover, UK); $100 \mathrm{ng} / \mathrm{ml}$ insulin (Novo Industri, Bagsvaerd, Denmark); $250 \mathrm{ng} / \mathrm{ml}$ growth hormone (Somatotropin, human recombinant; Kabi Pharmacia, Milton Keynes, UK); $1.5 \mathrm{nmol} / \mathrm{l}$ aldosterone (Sigma); 2 U platelet-derived growth factor (PDGF; Bioprocessing Ltd., Consett, UK); or $300 \mathrm{ng} / \mathrm{ml}$ insulin-like growth factor I (IGF-I; Kabi Pharmacia).

RPMI media containing $11.1 \mathrm{mmol} / \mathrm{l}$ glucose was prepared from $10 \times$ RPMI concentrate (supplemented with $11.1 \mathrm{mmol} / 1$ glucose) (Imperial Laboratories Ltd).

\section{RNA extraction and hybridisation}

RNA was extracted using the guanidinium isothiocyanate/phenol/chloroform/isoamylalcohol/isopropanol technique adapted from Chomocynski et al. [8]. RNA was analysed by electrophoresis in a $1 \%$ agarose formaldehyde gel and transferred to Hybond-N nylon hybridisation transfer membranes (Amersham Int. Amersham, Bucks, UK) by Northern blotting [9]. Membranes were hybridised with a highly specific preproinsulin cDNA probe (a kind gift of Dr. W.Kastern, University of Florida, Miami, Fl., USA) multiprime-labelled with AT $\alpha^{32} \mathbf{P}$ (Amersham Int:; $110 \mathrm{TBq} / \mathrm{mmol}$ ) to demonstrate fractionable, non-degraded RNA. Results were visualised by autoradiography. In addition, each RNA sample was analysed by dot blot hybridisation.

Bound preproinsulin cDNA was removed by high stringency washing $(10 \mathrm{mmol} / \mathrm{l}$ Tris-chloride, $\mathrm{pH} 7.6 ; 1 \mathrm{mmol} / 1$ EDTA, $\mathrm{pH} 8.0$; $\left.80^{\circ} \mathrm{C}, 60 \mathrm{~min}\right)$. Autoradiography was employed to determine complete removal.

Membranes were re-hybridised with a highly specific reg cDNA probe multiprime labelled with $\mathrm{AT} \alpha^{32} \mathrm{P}$ (Amersham Int; $110 \mathrm{TBq} / \mathrm{mmol}$ ) to semi-quantify reg gene expression. Results were visualised by autoradiography $\left(24 \mathrm{~h}\right.$ exposure at $\left.-70^{\circ} \mathrm{C}\right)$. Dot blot autoradiographs were analysed by densitometry. Signal intensity was expressed as a percentage of control.

\section{Thymidine incorporation}

Islet replication was estimated by the culture of groups of 40 of the remaining islets in their original media for $24 \mathrm{~h}$ to which methyl ${ }^{3} \mathrm{H}$ thymidine (Amersham Int.) at a concentration of $1 \mu \mathrm{Ci} / \mathrm{ml}$ had been added. Non-specifically bound methyl ${ }^{3} \mathrm{H}$-thymidine was removed by washing islets in HBSS containing $10 \mathrm{mmol} / \mathrm{l}$ unlabelled thymidine (Sigma) for $2 \mathrm{~min}$. The islets were finally washed in HBSS alone, transferred to distilled water and sonicated on ice. DNA was precipitated by the addition of $5 \%$ ice cold tri-chloroacetic acid and trapped onto glass fibre discs (Whatman $\mathrm{GF} / 2,2.5 \mathrm{~cm}$ ) by suction filtration, on a glass sinter. Discs were dried $\left(50^{\circ} \mathrm{C}, 12 \mathrm{~h}\right)$ and radioactive disintegrations counted (scintillant: Ecolume; ICN Biomedieals Inc.).

The protein content of the islets was estimated in the remaining islet sonicate using a protein Coomassie blue binding assay system (Bio-Rad Laboratories, Hemel Hempstead, UK) as per the manufacturer's instructions. Results were finally expressed as $\mathrm{cpm} / \mu \mathrm{g}$ islet protein.

\section{Statistical analysis}

Data are expressed as mean \pm SD. Student's $t$-test was used to determine the signficance of differences between control and test groups in thymidine uptake and reg gene expression.

\section{Results}

With the single exception of IGF-I, all growth factors significantly stimulated reg gene expression and thymidine uptake in cultured islets. The responses were not due to a factor or factors in minimally supplemented RPMI, which was used as the control for each experiment.

Mean thymidine uptake of islets cultured in control media was $1118 \pm 100(\mathrm{SD}) \mathrm{cpm} / \mu \mathrm{g}$ islet protein, $n=15$. Thymidine uptake was stimulated by: $11.1 \mathrm{mmol} / \mathrm{lglucose}$ $(1846 \pm 233(\mathrm{SD}) \mathrm{cpm} / \mu \mathrm{g}$ islet protein, $n=5$; mean increase $50 \%, p<0.05$ ); amino acids at a concentration five times greater than that in basal RPMI $(2503 \pm 310 \mathrm{cpm} / \mu \mathrm{g}$ islet protein, $n=5$; mean increase $126 \%, p<0.01) ; 10 \%$ fetal calf serum $(1564 \pm 89 \mathrm{cpm} / \mu \mathrm{g}$ islet protein, $n=5$; mean increase $39 \%, \quad p<0.01) ; 100 \mathrm{ng} / \mathrm{ml}$ insulin $(1622 \pm 116 \mathrm{cpm} / \mu \mathrm{g}$ islet protein, $n=5$; mean increase $45 \%, p<0.01) ; 500 \mathrm{ng} / \mathrm{ml}$ growth hormone $(1785 \pm$ $169 \mathrm{cpm} / \mu \mathrm{g}$ islet protein, $n=5$; mean increase $65 \%$, $p<0.01) ; 1.5 \mathrm{nmol} / 1$ aldosterone $(1460 \pm 109 \mathrm{cpm} / \mathrm{\mu g}$ islet protein, $n=5$; mean increase $29 \%, p<0.05) ; 1 \mathrm{U} / \mathrm{ml}$ PDGF $(2421 \pm 373 \mathrm{cpm} / \mu \mathrm{g}$ islet protein, $n=5$; mean increase $116 \%, p<0.05) ; 300 \mathrm{ng} / \mathrm{ml}$ IGF-I $(941 \pm 95 \mathrm{cpm} / \mu \mathrm{g}$ islet protein, $n=5$; no increase).

Figures 1 and 2 show Northern blots of the same islet RNA sample hybridised with the radiolabelled preproinsulin and reg cDNA probes respectively. The single discrete bands seen indicate specific binding to preproinsulin and reg mRNA, and further confirm the presence of intact, fractionable RNA. The figures also show semiquantitative dot blots of the same RNA. Each column of dots represents eight serial doubling dilutions of the RNA extract. Signal intensity of the dots reflects the amount of preproinsulin or reg RNA present. The lanes are comparable with each other, since the same amount of RNA 


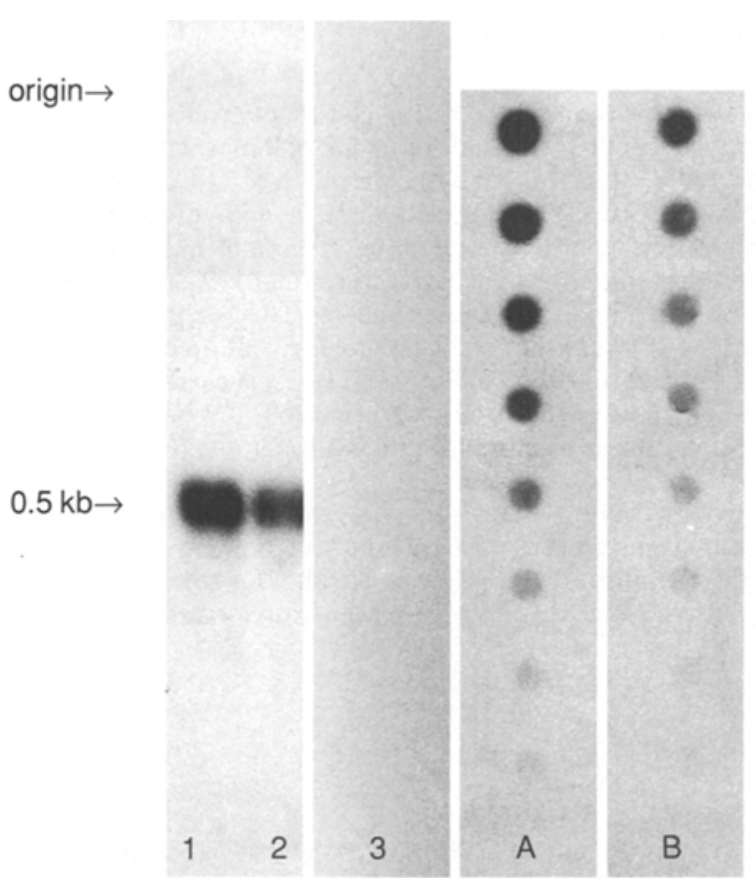

Fig.1. Northern blots illustrate non-degraded RNA and specificity of preproinsulin probe. Dot blots express semi-quantitatively the dose-dependency of preproinsulin gene message expressed by preparations of collagenase isolated rat islets exposed to glucose. Northern blot lanes 1-3 correspond to rat islet RNA probed with synthetic preproinsulin oligoprobe (lane 1, $11.1 \mathrm{mmol} / \mathrm{l}$ glucose; lane 2, $2.7 \mathrm{mmol} / 1$ glucose; lane 3 , rat liver control). Dot blots show same preparation of islet RNA, each lane in doubling dilutions starting at 1 ug (lane A, $11.1 \mathrm{mmol} / 1$ glucose; lane B, $2.7 \mathrm{mmol} / 1$ glucose)

$(1 \mu \mathrm{g})$ was blotted on to each membrane, and the amount of reg gene expression can be related to thymidine uptake as both were measured in the same islet culture. Figures 1 and 2 show the effect of increasing glucose concentrations on preproinsulin and reg mRNA expression respectively. Both preproinsulin and reg mRNA expression are increased by increased glucose concentration. Table 1 shows results obtained by densitometry of the dot blots where RNA samples have been probed with reg cDNA. The data shows that, given the concentrations of growth factors used in these studies, the rank order for reg gene expression was the same as that for thymidine uptake (Fig. 3, with a correlation coefficient $r=0.90$ ).

\section{Discussion}

This study is the first to show increased reg gene expression in response to individual growth factors. Thymidine uptake is a measure of DNA (and therefore cell) replication $[10,11]$; the close relationship between reg gene expression and thymidine uptake in these studies suggests that the reg gene is intimately associated with cell growth.

In selecting growth factors for this study, we felt it important to identify nutrients and hormones already known to increase Beta-cell replication. Furthermore, in order to

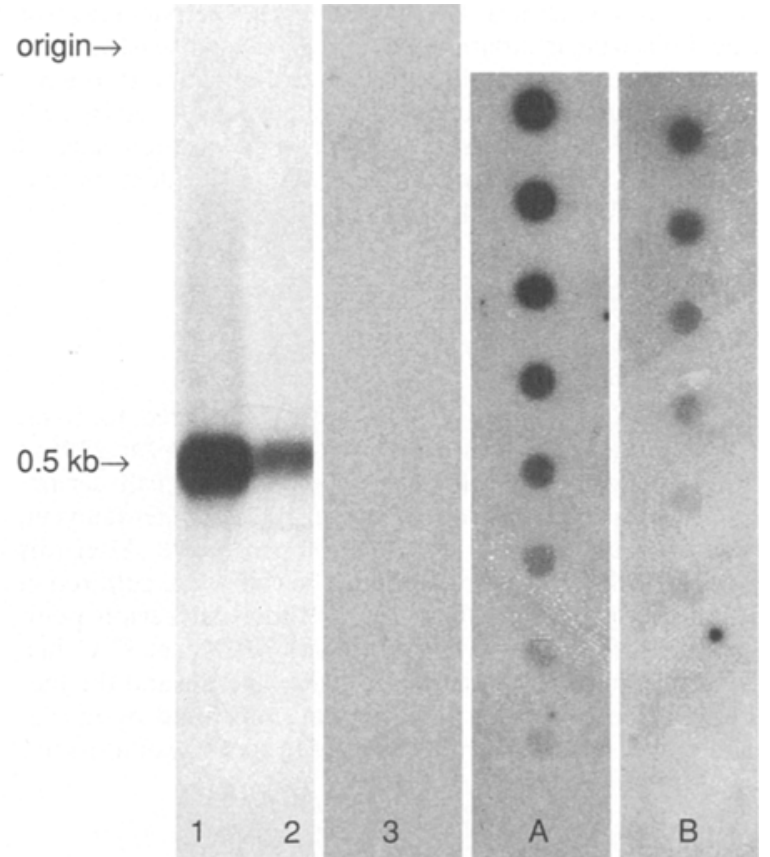

Fig. 2. Northern blots to illustrate non-degraded RNA and specificity of reg probe. Dot blots to express semi-quantitatively the dosedependency of reg gene message expressed by preparations of collagenase isolated rat islets exposed to glucose. Northern blot lanes 1-3 correspond to rat islet RNA probed with synthetic reg oligoprobe (lane 1, $11.1 \mathrm{mmol} / 1$ glucose, lane 2, $2.7 \mathrm{mmol} / 1$ glucose; lane 3 , rat liver control). Dot blots show same preparation of islet RNA, each lane in doubling dilutions starting at $1 \mu \mathrm{g}$ (lane A, $11.1 \mathrm{mmol} / \mathrm{l}$ glucose; lane $\mathrm{B}, 2.7 \mathrm{mmol} / \mathrm{l}$ glucose)

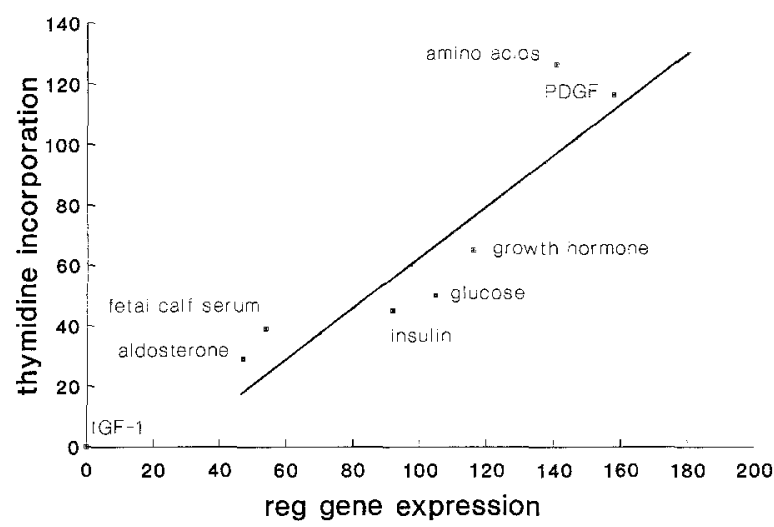

Fig.3. Correlation between reg gene expression in rat islets exposed to various nutrients and non-nutrient hormones, and thymidine incorporation into the same preparations. Both data sets expressed as percentage of expression in minimally supplemented RPMI. $r=0.90(p=0.006)$

seek evidence for a global association between reg gene expression and growth, hormones known to act through a variety of growth-promoting second messenger pathways were chosen. Our experiments showed increased DNA synthesis in islets cultured in media supplemented with nutrients such as glucose, amino acids or fetal calf serum (which contains as yet uncharacterised concentrations of hormones and nutrients), and with hormones such as 
Table 1. Data (arbitrary units) obtained by densitometry of dot blots in which the RNA from rat islets exposed to nutrient and non-nutrient hormones, was probed with reg cDNA

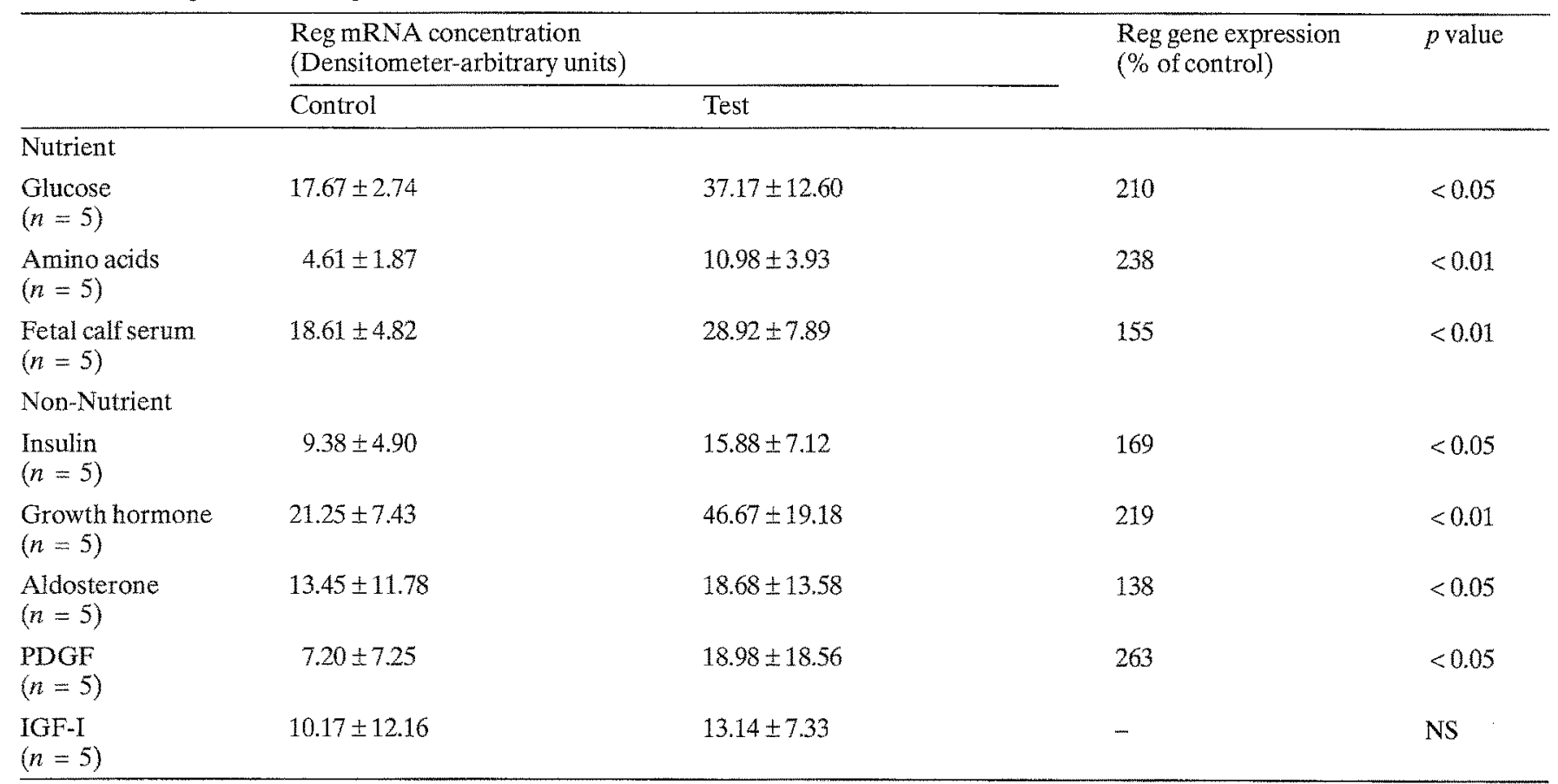

Results expressed as mean \pm SD for the number of paired observations given in parentheses

PDGF, platelet derived growth factor; IGF-I, insulin-like growth factor I

insulin, growth hormone and aldosterone. Concomitant with the increase in thymidine uptake was a rise in reg gene transcription. Although it is possible that non-islet cells may contribute to the observed increases in thymidine incorporation, the maintenance of islets in non-adherent culture dishes prevented any contamination by anchorage-dependent, non-endocrine cells such as fibroblasts.

Several mechanisms have been proposed to account for the apparent growth promoting effects of insulin. In vitro studies have demonstrated that insulin may act via the type 1 IGF receptor [12], or less commonly via its own receptor [13], to exert a mitogenic response. Insulin action via the type 1 IGF receptor is only observed at micromolar concentrations, concentrations which are unlikely to be seen in vivo. In addition to these direct mechanisms, insulin may potentiate the action or enhance the local synthesis of growth factors including the IGF's [14]. Furthermore, insulin may increase the number of growth hormone receptors in target tissues [14], or potentiate growth hormone signal transduction at some post-receptor step and in this way increase IGF-I synthesis [15].

The growth promoting mechanisms of growth hormone are incompletely understood. Some of the activity may be mediated through the generation of IGF-I either in the liver [16] or locally in different target tissues [17]. Recent studies have pointed to a direct action of growth hormone [18]. The present study does not exclude the local generation of IGF's by the target cells, but does suggest that growth hormone has a direct effect on islets independent of IGF's generated by the liver.
In our experiments, PDGF induced a marked increase in islet cell thymidine uptake. Interestingly, the pancreas is the only tissue of non-mesodermal origin yet known to respond to PDGF [19]. The role of IGF-I in growth induction is unclear, though it appears that PDGF can act both independently and in synergy with IGF-I [19].

The effects of steroids on islet growth are well researched, particularly because of their involvement in growth, maturation and pregnancy [11]. Aldosterone appears to be the only steroid that induces growth in a dosedependent manner [20], and in our studies induced a significant increase in both islet growth and reg gene expression.

We have been unable to confirm previous studies which suggested that IGF-I increases radiolabelled thymidine incorporation in islets [19]. This disparity may be due to our use of sub-physiological concentrations of glucose, which are known to inhibit IGF-I activity [19], to our use of adult as opposed to fetal rat islets or to a lack of biological potency in the preparation of IGF-I used. Nevertheless, we can safely conclude that wherever growth was induced, reg gene expression was increased, and that when no growth was observed, as in the case of exposure to IGF-I, no increase in reg gene expression was detected either. Additionally, the level of thymidine uptake shows a strong correlation with the level of reg gene transcription.

The reg gene product also identified as "pancreatic stone protein" [4], contains secretory signal peptides, and it has been localised in the secretory granules of the Beta cells [3] and mature exocrine pancreas [6]. However, the major sites of reg expression still remain contentious. Immunocy tochemical studies show apparent preferential ex- 
pression of reg protein in islets during regeneration induced by partial pancreatectomy and nicotinamide injection, although some immunostaining was observed in exocrine cells as well [3] and a recent report concluded that the dramatic rise in reg expression following insulinoma removal could not be accounted for by changes in the islets alone [6].

Studies predicting the three-dimensional structure of reg protein suggest homology with the lectins [4,5], a family of proteins with diverse roles involved in growth promotion, tissue recognition, intercellular communication and immunomodulation. Furthermore, the expression of reg occurs in colonic and rectal tumour but not in all tumour cells [3], linking enhanced reg expression to the transformed proliferation for at least some cells.

The results presented here provide evidence for an association between reg gene expression and islet cell replication. It seems unlikely that this was a non-specific effect, since at least one of the proteins (IGF-I) failed repeatedly to simulate the system. Reg gene appears to be implicated in the "final common pathway" to cell replication as each of the hormone/nutrients used in this study utilises a different second messenger system. The report provides a basis for further clarification of the mechanisms by which growth factors induce cell growth.

Acknowledgements. This work was supported by grants from the British Diabetic Association and Glaxo Research Laboratories (North Carolina, USA). We are greatly indebted to Prof. H.Okamoto for his kind support and gift of the reg cDNA probe and are indebted to Dr. S.-L. Zhang and Ms. S. Banister for technical advice and Mrs. W.Couper for careful preparation of the manuscript.

\section{References}

1. Oakley WG, Pyke DA, Taylor KW (1973) Biochemical basis of diabetes. In: Diabetes and its management. Blackwell Scientific Pubs, Oxford, pp 1-12

2. Terazono K, Yamamoto H, Takasawa S et al. (1987) A novel gene activated in regenerating islets. J Biol Chem 263: 2111-2114

3. Terazono K, Uchijama Y, Ide M et al. (1990) Expression of reg protein in rat regenerating islets and its co-localisation with insulin in the Beta-cell secretory granules. Diabetologia 33: 250252

4. Patthy L (1988) Homology of pancreatic stone protein with animal lectins. Biochem J 253:309-311

5. Peterson TE (1988) The amino terminal domain of thrombomodulin and PSP are homologous with lectins. FEBS Lett 231: $51-53$

6. Miyaura C, Ling C, Appel M et al. (1991) Expression of reg/PSP, a pancreatic exocrine gene: relationship to changes in islet Betacell mass. Mol Endocrinol 5: 226-234
7. Hehmke B, Kohnert KD, Odselius R (1986) The use of a new dextran gradient for the isolation of functionally intact neonatal pancreatic islets. Diab Res 3:13-16

8. Chomoczynski P, Saachi N (1987) Single step method of RNA extraction by acid guanidinium isothiocyanate-phenol-chloroform extraction. Analyt Biochem 162: 156-159

9. Maniatis T, Fritsch RF, Sambrook J (1982) Molecular cloning: a laboratory manual. Cold Spring Harbour Laboratory

10. Swenne I, Bone AJ (1981) Effects, in tissue culture, of serum from obese mice on the DNA synthesis of the pancreatic Betacell. Cell Biol Int Rep 5: 215-221

11. Hellerström C, Swenne I (1985) Growth pattern of pancreatic islets. In: Volk B, Arquilla $\mathrm{E}$ (eds) Animals in the diabetic pancreas. Plenum Corp, pp 53-59

12. King GL, Kahn CR, Rechler MM, Nissley SP (1980) Direct demonstration of separate receptors for growth and metabolic activities of insulin and multiplication-stimulating activity (an insulin-like growth factor) using antibodies to the insulin receptor. J Clin Invest 66: 130-140

13. Koontz JW, Iwahashi M (1981) Insulin as a potent, specific growth factor in a rat hepatoma cell line. Science 211: 947-949

14. Baxter RC, Bryson JM, Turtle JR (1980) Somatic receptors of rat liver: regulation by insulin. Endocrinology 107: 1176-1181

15. Maes M, Ketelsegers J-M, Underwood JM (1983) Low plasma somatomedin- $\mathrm{C}$ in streptozotocin-induced diabetes mellitus. Correlation with changes in somatogenic and lactogenic liver binding sites. Diabetes 32: 1060-1069

16. Schwander JC, Hauri C, Zapf J, Froesch FR (1983) Synthesis and secretion of insulin-like growth factor- 1 and its binding protein by the perfused rat liver: dependence on growth hormone status. Endocrinology 113: 297--305

17. D'Ercole AJ, Stiles AD, Underwood LE (1984) Tissue concentrations of somatomedin C: further evidence for multiple sites of synthesis and paracrine or autocrine mechanisms of actions. Proc Natl Acad Sci USA 81: 935-939

18. Isgaard J, Nilsson A, Lindahl A, Jansson J-O, Isaaksson OGP (1986) Effects of Iocal administration of growth hormone and insulin-like growth factor-1 on longitudinal bone growth in rats. Am J Physiol 250: E367-E372

19. Swenne I, Heldin CH, Hellerström C (1988) Effects of PDGF and SM-C/IGF-I on the DNA replication of fetal rat islets of Langerhans in tissue culture. Endocrinology 122:214-218

20. McEvoy RC, Hegre OD, Lazarow A (1976) Foetal rat pancreas in organ culture. Effect of corticosterone concentrations on the acinar and islet cell components. Differentiation 6:17-26

Received: 17 June 1991

and in final revised form: 8 November 1991

Dr. A.J.Bone

Endocrine Section

Medicine II

Southampton General Hospital

Southampton SO9 4XY

UK 